\title{
Study of Social Vulnerability of Climate Change at the Mountain Ecosystem
}

\author{
Muhammad Rifqi Maulana ${ }^{1}$ and Denny Nugroho Sugianto ${ }^{1,2}$ \\ ${ }^{1}$ Magister Program of Environmental Science, School of Postgraduate Studies, Diponegoro University, Semarang - Indonesia \\ ${ }^{2}$ Departemen of Oceanography, Faculty of Marine Science and Fisheries, Diponegoro University, Semarang - Indonesia
}

\begin{abstract}
Climate change is a global phenomenon, where the impact will be experienced by all parts of the world. One of the areas studied was Indonesia. Climate change in Indonesia has the direct and indirect effect on aspects of human life. Climate change can cause ecosystem disturbances. One of which is a mountainous ecosystem on Mount Rinjani, Lombok Island. The mountain ecosystem is very similar to the climate in Indonesia, this will have a special impact on the agricultural sectors. Therefore it is necessary to know the level in their environment. This paper will discuss social measurement parameters and their impact on climate in mountain ecosystems. The main factors are ecosystems (control environment, settlement patterns), ecology (forest cover, cliff conditions) and economy (livelihood \& income / natural resources)
\end{abstract}

Keywords: social vulnerability ; climate change ; mountain ecosysyem.

\section{Introduction}

Climate change occurs in various parts of the world, causing changes in rainfall patterns, air temperature, causing some extreme climate events in the form of floods and droughts. Those are some of the serious impacts of climate change faced by the world community, including Indonesia [1]. As a result of climate change within the period $1991-2000$ which increased three-fold compared to 1981 - 1990 Indonesian farmers experienced crop failure and loss of rice production [2]. The negative impact of global climate change on the economy is considered to cause the loss of $5 \%$ of the world's Gross Domestic Product (GDP) every year [3].

Climate change results in seasonal shifts and changes in rainfall patterns that are very influential in various sectors, some of them are the disruption of the planting season and harvest season which can pose a threat to food security [4]. The agricultural economy sector is also disrupted. The production of fertilizers was hampered and decreasing number on farmers' food stock. On the other hand, high rainfall with increasing intensity can increase the risk of landslides, especially if the vegetation cover is very low. The threat of landslides, the stability of food production and forest ecosystems are commonly in the highlands. Global climate change will be felt differently across regions depending on local impacts and the strengths in their communities [5]. Province of West Nusa Tenggara (NTB) is one of the regions of Eastern Indonesia that is very vulnerable to climate change [6]. Every time rainy season starts, NTB people must be alert to face disasters due to meteorological factors. The phenomenon of heavy rain and strong winds can trigger floods and landslides, and it can damage houses. In this case, property losses are unavoidable. Rain with heavy intensity, long duration, and uneven distribution of rainfall has the potential to cause floods and landslides in some regions.

One party that feels the effects of climate change and extreme weather that occur, directly and indirectly, is the local people themselves [7]. Improving community capacity is crucial in ensuring the success of adaptation to climate change [8], especially changes regarding the reactive adaptation approach become proactive [9]. Thus, the vulnerability of the local people to climate change that occurs is an important part to provide information in a variety of different areas, as well as reference material for planning adaptation actions that enhance the adaptive capacity of the system [10].

One of the efforts in reducing the risk of threats is by preparing the local community to understand the standby action. However, in the mountainous area, it is still unknown which community groups are vulnerable to climate change and how vulnerable they are. What are the main factors causing this vulnerability? And are there recommendations that can be submitted regarding the level of vulnerability due to climate change? And how appropriate are mitigation efforts to the conditions of the community and its ecosystem? These problems are 
fundamental and important issues to be studied in order to formulate adaptation strategies so that efforts can be made to reduce risk and strengthen the community capacity for the impacts of climate change.

Based on the study above, this research aims to determine the level of vulnerability of the community in mountainous ecosystems toward climate change. The Vulnerability is defined as a natural condition that is influenced by several aspects; physical processes, social, economic and environmental processes that can pose a risk to the impact of hazards [11]. Climate change is defined as the global climate situation that is experiencing changes due to natural changes and anthropogenic (human) factors. Symptoms of climate change according to climatic indicators are identified on a global scale and can not be identified on a local scale [12].

\section{Methodology}

This research is descriptive based on the literature study that has been conducted by several researchers, with the object of research is Lombok Island. The stage of this research was conducted to determine the level of vulnerability of the community in the mountain ecosystem toward climate change. Vulnerability is defined as a condition that is affected by physical, social, economic and environmental processes that can increase the risk to the impact of hazards [13]. And the results' analysis of its implementation is shown in the form of "maps of disaster-prone areas".

\subsection{Data Collection}

Primary data was taken by direct observation in the field and interviews. This primary data relates to the physical, social, economic and regional distribution conditions of landslides and community disaster mitigation in facing landslides. In each region, 40 respondents were chosen to represent various community groups. Among these respondents, there were key informants, such as community leaders as local knowledge experts according to Davis and Wagner criteria [14]. Secondary data was taken from related institutions; Lombok Forestry Service, Lombok Island Public Works Agency, BMKG, Gunung Rinjani National Park.

\subsection{Data Analysis}

Assessment Vulnerability analysis was conducted using the formulation of the Intergovernmental Panel on Climate Change [15] that vulnerability is a function of exposure, sensitivity, and adaptive capacity. Exposure is a degree (how far) a system (social and ecosystem) naturally susceptible to climate change. Sensitivity is a system that is affected by all elements of climate change, including the characteristics of the average climate, climate variability, frequency, and extreme quantities. Adaptive capacity is the ability of a system to cope with the consequences of change or adapt to climate change, reducing the potential for natural damage.

\subsubsection{Outcrop}

Exposure Factor was measured using an analysis of causality between climate variables (temperature and rainfall) with climatic hazard related to human life according to the relevant Economy and Environment Program for Southeast Asia \& International Development Research Center [16] in mountain ecosystems; landslide. Assessment of landslidespotential exposure was conducted according to Suranto's approach.

\subsubsection{Sensitivity}

Sensitivity was analyzed by scoring method. The sensitivity aspects analyzed was including social, economic, infrastructure and ecological aspects [17] developing criteria and indicators. The total values for each location and attributes/indicators were classified using the interval scale (SI). interpreted into three classes of vulnerability (sensitivity); high, medium and low

\subsubsection{Adaptive Capacity}

Adaptive capacity was analyzed using the scoring method. The aspects of adaptive capacity analyzed were the same aspects as sensitivity variables; social, economic, infrastructure and ecology [18] If the indicator shows weakening signal, it is classified as sensitive, and if it strengthens, it is classified as adaptive capacity.

\section{Result and Discussion}

\subsection{Climate Change in the Mountain Ecosystem}

One of the consequences of climate change can be seen from the rain pattern. The nature of rainfall is a comparison between the amount of rainfall that occurs during a month with the average or normal rainfall of the month in an area [19], which can be grouped into normal rain $(\mathrm{N})$, above normal (AN) and below normal $(\mathrm{BN})$. The nature of rain at the research site tends to be below normal in the middle of the year and above normal at the end of the year. These dynamics indicate atmospheric disturbances, some disturbances on local and regional scales that affect rainfall in the Mountainous region.

The local communities in the research location have felt changes in temperature and rainfall patterns. All respondents stated that the community felt the increasing temperature. Most respondents stated that the change in rainfall patterns became irregular, higher intensity, but shorter duration. Most people in the mountains have agricultural livelihoods with horticultural commodities such as shallots, scallions, cabbage, tomatoes, corn, and other crops. Changes in temperature and rainfall patterns have influence in declining the productivity of horticultural crops. The reduction in productivity is technically caused by a mismatch between the needs and the availability of water which causes crop failure or a reduction in the quality and quantity of fruits. In addition, the emergence of plant disease (pests) was triggered by changes in temperature and rainfall patterns. It was also considered as one of the causes of the decline in the quality and quantity of crops. Decreasing productivity in agriculture at the research site 
was higher than the results of a study by Muhammad et al. [20], which in the wetter climate, it causes an increasing agricultural failure from $0.24-0.73 \%$ to be $8.7-13.8 \%$.

\subsection{Community Vulnerability Level on Climate Change}

\subsubsection{Landslides as the focus of outcrops}

Based on the theoretical functional relationship, landslides can occur due to several controlling factors; slope conditions, soil / rock constituent conditions, geological conditions, hydrological conditions on slopes, and land use on slopes. Climate and rainfall trigger landslides, especially when high rainfall intensity occurs continuously for several hours, days or weeks. Assessment of landslide potential / vulnerability is formed by three indicators; slope, rock / soil compiler, and rainfall.

Based on slope indicators, the three villages have a high potential for landslides because the land's slope is $>45$. Despite the hilly-mountainous topography with high slopes, people continue to use the land as a settlement and agricultural site. Community efforts to reduce landslide risk is only using the terracing technique. The potential for high ground movements is proved by the frequency of landslide events at the research site. In addition to large landslides there are also small landslides, such as the movement of soil in small masses and does not cause mass damage. The frequency of small landslides at the research site is very high due to hilly conditions, with many plain areas. Many of the residents' gardens have been destroyed by landslides and the locations are spread sporadically. This confirms the record of disaster events in Indonesia, that $53 \%$ of the total disasters are hydrometeorological disasters, the most frequent disasters were floods (34.1\%) and landslides (16\%) [21]. approach.

\subsubsection{Sensitivity and adaptive capacity}

Sensitivity and adaptive capacity are influenced by four aspects; social, ecological, infrastructure and economy. According to spatial distribution, the level of community sensitivity to climate change in the mountainous ecosystem in the observation site is in the medium and high category.

\section{Conclusion and Suggestion}

\section{A. Conclusion}

The main factors of vulnerability in mountainous ecosystems are infrastructure, ecological factors, and economic factors. Infrastructure factors are: the absent of landslide control buildings, and settlement patterns are mostly located in cliff areas. Ecological factors are: forest cover $<30 \%$, and many unstable cliff conditions. The economic factors are the people's occupation that has a high dependency on the land and natural resources. Disaster mitigation efforts are divided into 3 parts; predisaster, during disaster and post-disaster. The efforts at pre-disaster are prevention before the occurrence of landslides by participating in disaster response training. During the disaster, it is an effort to save themselves and send disaster alert to other communities. And after the disaster, it is an effort to reconstruct infrastructure that was damaged by a disaster.

\section{B. Suggestion}

The efforts to reduce the level of community vulnerability are important for several things, including the physical development of cliff control, settlement arrangements to avoid landslides, enrichment of woody plants in the land with slope $>45$, and expansion of protected forests.

For the community, they must take part in training to find out and understand disaster-related knowledge. And for the government, it is better to show which areas are prone to landslides and to socialize and provide counseling to the community, especially to disasterprone areas.

\section{References}

[1] Badan Perencanaan Pembangunan Nasional \& Badan Koordinasi Nasional Penanganan Bencana. (2006). Rencana aksi nasional pengurangan risiko bencana 2006-2009. Jakarta: Badan Perencanaan Pembangunan Nasional dan Badan Koordinasi Nasional Penanganan Bencana.

[2] Benson C.,Twigg, J.,\&Rossetto,T. (2007). Perangkat untuk mengarusutamakan pengurangan risiko bencana: catatan panduan bagi lembagalembaga yang bergerak dalam bidang pembangunan. Switzerland: Provention Consortium.

[3] Badan Meteorologi, Klimatologi \& Geofisika. (2011). Analisis hujan bulan Agustus 2011 dan prakiraan hujan bulan Oktober, November dan Desember 2011 Sumatera Barat. Sicincin: Stasiun Klimatologi Sicincin.

[4] Cammeraat, E., van Beek, R., \& Kooijman, A. (2005). Vegetation succession and its consequences for slope stability in Se Spain. Plant and Soil, 278, 135-147.

[5] Davis, A. \&Wagner, J.R. (2003).Who knows? On the importance of identifying "experts" when researching local ecological knowledge. HumanEcology, 31(3), 463-489.

[6] Departemen for International Development. (2012). Adaptation stories. Canada: Departmen for International Development - IDRC. Economy and Environment Programme for Southeast Asia \& International Development Research Center. (2009). Climate matters in Southeast Asia. Los Banos, Laguna, Philipines: Economy and Environment Programm for Southeast Asia and International Development Research Center

[7] Hairiah, K., Widianto, Suprayogo, D., Lestari, N.D., Kurniasari, V., Santosa, A., ..., \& van Noordwijk, M. (2006). Root effects on slope stability in Sumberjaya, Lampung (Indonesia). Paper was presented in "International Symposium toward Sustainable Livelihood and Ecosystems in Mountanious Regions"ChiangMai, 7 - 9 March 2006.

[8] Haque, M.A., Yamamoto, S.S., Malik, A.A., \& R. Sauerborn. (2012). Households' perception of climate change and human health risks: a 
community perspective. Environmental Health, 11, 1.

[9] Herawaty, H. \& Santoso, H. (2007). Pengarusutamaan adaptasi perubahan iklim ke dalam agenda pembangunan: tantangan kebijakan dan pembangunan. Adaptasi terhadap bahaya gerakan tanah di masa yang akan datang akibat pengaruh perubahan iklim. (Laporan). Dialog Gerakan Tanah dan Perubahan Iklim, 7-8Desember 2006. Bogor: CIFOR. 11, 1.

[10] Intergovermental Panel on Climate Change. (2001). Impacts, adaptation and vulnerability. Contribution of Working Group II to the Third Assessment Report of the Intergovernmental Panel on Climate Change. Cambridge and New York: Cambridge University Press.

[11] Montgomery, D.R., Schmidt, K.M., Greenberg, H.M., \& Dietrich, W.E. (2000). Forest clearing and regional landsliding. Geology, 28(4), 311-314.

[12] Muhamad, A., Aryoseno, A., \& Yuliantri, R. (2011). Rencana aksi nasional adaptasi perubahan iklim di Indonesia. Jakarta: Dewan Nasional Perubahan Ikllim

[13] O'Loughlin, C. \& RR. Ziemer. (1982). The importance of root strength and deterioration rates upon edaphic stability in steepland forests. Forest Research Institute, Christchurch, New Zealand and USDA Forest Service, Arcata, California.

[14] Pasaribu, S.M.,Mayrowani,H., Swastika,D.K., Iqbal, M.,Zakaria,A.K.,Nurasa, ...,\&Heslina, J. (2008). Peningkatan kapasitas adaptasi petani di daerah marjinal terhadap perubahan iklim (Laporan Penelitian). Bogor: Pusat Analisis Sosial Ekonomi danKebijakan Pertanian.

[15] Pawitan, H. (2010). Arti perubahan iklim global dan pengaruhnya dalam pengelolaan daerah aliran sungai di Indonesia. Makalah Ekspose Hasil Litbang Balai Penelitian Kehutanan Solo: "Pengelolaan DAS dalam Mitigasi dan Adaptasi Perubahan Iklim di Indonesia", Surakarta, 28 September 2010. Solo: Balai Penelitian Kehutanan Solo.
[16] Prawiradisastra, S. (2007). Bencana tanah longsor di Kecamatan Lembah Gumanti, Kabupaten Solok, Sumatera Barat. Alami, 12(2), 66-71. Diunduh dari .(27Oktober 2012).

[17] Rochmayanto, Y., Sakuntaladwi, N., Wibowo, L.R., \& Kurniasih, P. (2013). Woman in climate change: gender representation in reducing poverty and protecting livelihood in mountainous ecosystem at Solok District, West Sumatra (397407). Proceeding the Second International Conference of Indonesian Forestry Researchers (INAJurnal Analisis Kebijakan Kehutanan Vol. 12 No. 2, Agustus 2015 : $189-201201$

[18] Suranto, J.P. (2008). Kajian pemanfaatan lahan pada daerah rawan bencana tanah longsor di Gunung Lurah, Cilongok, Banyumas. (Tesis). Pascasarjana Universitas Diponegoro, Semarang. Tim Sintesis Kebijakan Departemen Pertanian. (2008). Dampak perubahan iklim terhadap sektor pertanian, serta strategi antisipasi dan teknologi adaptasi. Pengembangan Inovasi Pertanian, 1(2), 138-140.

[19] Watkiss, P.,Downing, T.E.,\&Dyszynzki, J. (2010). Adapt cost project : analysis of the economic cost of climate change adaptation in Africa. Nairobi: United Nation Environment Programme.

[20] Watson, A., Phillips, C., \& Marden, M. (1999). Root strength, growth, and rates of decay: root reinforcement changes of two tree species and their contribution to slope stability. Plant and Soil, 217, $39-47$

[21] Ziemer, R.R. (1981). The role of vegetation in the stability of forested slopes (297-308). XVII IUFRO World Congress. Japan, 1981. Japan: International Union of Forest Research Organizations. Zhou, Y., Watts, D., Cheng, X., Li, Y., Luo, H., \& Xiu, Q. (1997). The traction effect of lateral roots of Pinus yunnanensis on soil reinforcement: a direct in situ test. Plant and Soil, 190, 77-86. 